DIAS, NO; REBOUÇAS, TNH; SÃO JOSÉ, AR; AMARAL, CLF. 2017. Morpho-agronomic characterization and estimates of genetic parameters in annatto plant. Horticultura Brasileira 35: 242-246. DOI - http://dx.doi.org/10.1590/S0102-053620170214

\title{
Morpho-agronomic characterization and estimates of genetic parameters in annatto plant
}

\author{
Nilma O Dias'; Tiyoko NH Rebouças'; ${ }^{1}$ Abel R São José1; Cláudio LF Amaral² \\ ${ }^{1}$ Universidade Estadual do Sudoeste da Bahia (UESB), Vitória da Conquista-BA, Brasil; nodias@gmail.com; tiyoko@uesb.edu.br; \\ abeljose3@gmail.com; ${ }^{2}$ Universidade Estadual do Sudoeste da Bahia (UESB), Jequié-BA, Brasil; materdidatic@gmail.com
}

\begin{abstract}
Originally from tropical America, annatto is an important source of natural dyes for food, pharmaceutical and textile industries, especially for the increasing demand of this pigment substituting artificial dyes. The aim of this study was to evaluate genotypic variation of annatto cultivar Embrapa 37, aiming to generate subsidies for breeding programs as well as to help out the producers using vegetative propagation of superior genotypes. Therefore, the morphological characterization was carried out and estimates of genetic and phenotypic parameters, for production and quality of the fruits, were obtained. The results showed wide rate of genetic variability among the plants with low environmental influence on the phenotype for traits bixin content, fruit width, number of fruits per bunch and mass of 100 seeds. The authors concluded that superior genotypes can be selected through the parental performance and propagated vegetatively to form more profitable crops, as well as used in breeding programs through self-fertilization with analysis of resulting progeny.
\end{abstract}

Keywords: Bixa orellana, natural dyes, heritability, genetic gain.

\begin{abstract}
RESUMO
Caracterização morfoagronômica e estimativas de parâmetros genéticos em urucuzeiro

Arbusto originário dos trópicos da América, o urucuzeiro representa uma importante fonte de corantes naturais para as indústrias alimentícia, farmacêutica e têxtil, especialmente, pelo aumento da demanda deste pigmento na substituição dos corantes artificiais. $\mathrm{O}$ objetivo deste trabalho foi avaliar variação genotípica da cultivar Embrapa 37 de urucuzeiro, visando gerar subsídios para programas de melhoramento genético, bem como, para atender aos produtores por meio da propagação vegetativa de plantas superiores. Para tanto, foi realizada a caracterização morfoagronômica e obtidas as estimativas de parâmetros genéticos e fenotípicos para características de produção e qualidade dos frutos. Os resultados demonstraram haver ampla taxa de variabilidade genética entre as plantas, com baixa influência ambiental sobre o fenótipo para as características teor de bixina, largura dos frutos, número de frutos por cacho e massa de 100 sementes. Concluiu-se que genótipos superiores podem ser selecionados pelo desempenho dos parentais e propagados vegetativamente para a formação de cultivos mais lucrativos, bem como, utilizados em programas de melhoramento genético através da autofecundação com análise de progênie resultante.
\end{abstract}

Palavras-chave: Bixa orellana, corante natural, herdabilidade, ganho genético.

\section{Received on January 29, 2016; accepted on November 10, 2016}

\begin{abstract}
$\mathrm{A}$ nnatto (Bixa orellana) is a shrub from American tropics; its dissemination over several continents is due to the broad demand as a source of natural colorant for several products such as medicine, cosmetics and, mainly, food (Silva \& Franco, 2000). Moreira et al. (2014) highlight functional properties present in Bixa orellana seed and suggest that its use as natural colorant benefits human health by the high antioxidant potential.

The carotenoid denominated bixin is the pigment present in greater
\end{abstract}

concentration in the pericarp of annatto seed, comprising more than $80 \%$ of the total carotenoids; it is fat soluble, so it is extracted using some organic solvents (Rebouças \& São José, 1996; Santana et al., 2008). Bixin contents may vary from 1.0 to $6.0 \%$ depending on the cultivar and on the environmental conditions of each region (Rebouças \& São José, 1996; Franco et al., 2008).

The last decade has been characterized by breeding species, aiming higher productivity and, mainly, higher pigment content. Bixin concentration surpassed the national average of $2.5 \%$ and productivity has already reached values superior than $1500 \mathrm{~kg} / \mathrm{ha}$ (Carvalho et al., 2010). These days, in order to be classified as exportation type, the grain has to present minimum bixin content of 4\% (Fabri \& Teramoto, 2015). Market requirements tend to become increasingly stringent with the emergence of improved cultivars.

Due to this fact, in the South Region of Bahia, cultivar Bico de Pato, which presented maximum content of $2.5 \%$, 
was substituted by cultivar Embrapa 37, developed in the State of Pará, which bixin contents were described by Poltronieri et al. (2001) reaching among 5 and $5.5 \%$. Thus, the authors highlight the importance of studies for making breeding programs feasible for certain regional conditions, aiming to guarantee the annatto agribusiness in the State of Bahia.

As the reproduction is predominantly by cross-pollination and propagation carried out via seeds, annatto cultivation presents high genetic variability, especially related to the seed number per capsule and to the pigment in seed teguments (Falesi, 1987). Mantovani et al. (2013) highlight that high productivity clonal plantations represent a feasible alternative and they can be established by vegetative propagation of superior genotypes of annatto.

Several grafting methods were tested by Bruckner et al. (1991), showing the viability of vegetative propagation for this crop, with the best yields obtained by the methods: budding, cleft grafting and splice graft. According to Rebouças \& São José (1996) through cutting, rooting percentual, under ideal conditions, can vary between 60 to $90 \%$. According to Mantovani et al. (2010), the vegetative rescue and the production of vegetative propagules of the species can be carried out successfully through layering, using total girdling of branches, treatment with IBA ( $4.92 \mathrm{mM})$ and branches protected with polyethylene film.

Despite the good experimental success of methods for vegetative propagation of annatto, these techniques are not usual in commercial deployment of the crop which is carried out using seeds, so evaluation on economic viability of these methods is important.

Considering the genetic variability, the authors observed that annatto cultivars show expressive variations related to morpho-agronomic traits, such as shape, color and capsule size, number of bunches per plant, capsule number per bunch and seed number per capsules (Rebouças \& São José, 1996). Agronomic characteristics have quantitative inheritance; therefore, they are governed by genes which have their expression strongly influenced by the environment (Franco et al., 2002). This fact makes it difficult to identify genotypes based only on the phenotype observed.

The difficulty in studying quantitative traits lies in the existence of the large number of genes involved and the pronounced effect of the environment (Lynch \& Walsh, 1998). In this sense, the estimate of genetic parameters is very important. Comprehending these estimates allows to understand the genetic structure of the population, to infer the genetic variance of this structure (Baldissera et al., 2014), to redefine breeding programs to be used, to identify the nature of action of the genes involved in controlling the quantitative traits, to define efficiently different breeding strategies in order to obtain genetic gains with the maintenance of the adequate genetic base in the population (Cruz \& Carneiro, 2006).

The aim of this study was to evaluate the annatto genotypes, cultivar Embrapa 37, for the conditions of the Extreme South of the State of Bahia, through morpho-agronomic characterization of the fruits and estimates of genetic parameters for production and quality traits.

\section{MATERIAL AND METHODS}

The experiment was carried out in a commercial cultivation at Fazenda Sempre Viva, located in the municipality of Eunápolis, Bahia State, Brazil, in a commercial plantation of cultivar Embrapa 37, four years old, spacing 6.0x3.0 meters.

The plantation is located in Mata Atlantica where the predominant vegetation is regenerating dirty pasture and coppice $\left(16^{\circ} 40^{\prime} \mathrm{S}, 39^{\circ} 34^{\prime} \mathrm{W}\right.$, altitude $141 \mathrm{~m}$ ); the region is characterized as tropical humid, without defined dry season; the local climate is AF, according to Köppen classification.

Ten genotypes of annatto plants were evaluated which constituted the main treatments (named from 1 to 10) with five replications, consisted of 10 fruits (capsules) each totalizing 50 fruits per treatment. The genotypes were visually selected considering fruit load, vigor and sanity of the plants, resulting in 500 plants preliminarily selected. A second selection was carried out for high bixin contents resulting in 200 plants in which the material for this study was defined, resulting in a selection index at 5\%.

Morphologic characterization of the fruits was carried out considering the following traits: colors of unripe fruits (red, reddish or green); length and width (using a digital caliper to measure the higher diameter, in $\mathrm{mm}$ ); shape in relation to length:width ratio (oval $=$ width equal or superior to $70 \%$ of length; lanceolate $=$ width less than $70 \%$ of length) according to the methodology described by Mantovani et al. (2013) and dehiscence observing the capsule opening, when the bunches were at harvesting time.

Production traits were estimated by the number of fruits per bunch, the number of seeds per fruit and the mass of 100 seeds. Evaluations were carried out after harvesting, on February 2, 2014, when the bunches presented at least $2 / 3$ of brown color capsules, considering each cardinal point (North, South, East, West). The samples were kept in polyethylene bags and sent to Biofábrica da Universidade Estadual do Sudoeste da Bahia where the laboratorial analyses were carried out.

In order to determine the bixin content, the seeds were removed from the capsules manually, put into paper envelopes and placed in a greenhouse at $40^{\circ} \mathrm{C}$, for $48 \mathrm{~h}$, until they reach $10 \%$ humidity. Four samples of the plants were used and analyzed using KOH method described by Yabiku \& Takahashi (1991).

Statistical analysis was carried out through the analysis of variance and comparing the averages using the statistical software SISVAR v. 5.3 (Ferreira, 2011). Estimates of genetic and phenotypic parameters were determined by the methodology presented by Sunday et al. (2007) and Oyiga \& Uguru (2010) using the following formula:

$$
\begin{aligned}
& \text { Genotypic Variability: } \\
& V g=\frac{M S g-M S e}{r}
\end{aligned}
$$


Phenotypic Variability:

$V p=\frac{M S g}{r}$

Environmental Variability:

$V e=M S e$

Where: $\mathrm{Vg}=$ genotypic variance; $\mathrm{Vp}=$ phenotypic variance; Ve $=$ environmental variance, $\mathrm{Msg}=$ mean squares of the genotype; Mse = mean square error and $r=$ number of replications.

Coefficient of Genotypic Variation:

$G C V=\frac{\sqrt{V g}}{\bar{X}} X 100$

Coefficient of Phenotypic Variation: $P C V=\frac{\sqrt{V p}}{\bar{X}} X 100$

Coefficient of Environmental Variation:

$$
E C V=\frac{\sqrt{V e}}{\bar{X}} X 100
$$

Where: GVC, PCV and $\mathrm{ECV}=$ coefficient of phenotypic variation, genotypic and environmental, respectively and $\bar{X}$ overall average of each treatment.

Heritability:

$$
h^{2}=\frac{V g}{V p}
$$

Where: $\mathrm{Vg}=$ genotypic variability and $\mathrm{Vp}=$ phenotypic variability.

Genetic Gain:

$$
G=i \Delta p h^{2}
$$

Where: $\mathrm{i}=$ constant (which corresponds to 2.06 when the selection intensity is $5 \%$ ); $\Delta \mathrm{p}=$ standard deviation of phenotypic variance and $\mathrm{h}^{2}=$ heritability.

\section{RESULTS AND DISCUSSION}

According to the morphologic characterization, the evaluated genotypes produce simple, dry, capsuled, loculicidal, bivalve, polyspermic, unilocular and dehiscent fruits. Mantovani et al. (2013) describe the same attributes for fruits produced from the artificial cross between the varieties "Fruto verde piloso" and "Fruto vermelho liso", with exception for dehiscence.

The authors observed from green to red colors for unripe fruits, becoming uniformly brown when mature, with pile; these characteristics were also described by Poltronieri et al. (2001) and Franco et al. (2008) for cultivar Embrapa 37.

The average performance for morpho-agronomic traits for the fruits is in Table 1. The authors noticed significant difference for fruit length (CF), fruit width (LF), number of fruits per bunch (NFC) and mass of 100 seeds (MCS); no statistical difference for number of seeds per fruit (NSF) was observed.

The data obtained for CF and LF were within the interval from 3.81 to $4.96 \mathrm{~cm}$ and from 3.02 to $3.52 \mathrm{~cm}$ respectively, which demonstrate variations among the genotypes evaluated in relation to the morphology of the fruits. Mendes et al. (2005), studying growth and ripening of annatto variety "Fruto Vermelho Piloso" found maximum values of 5.85 $\mathrm{cm}$ length and $3.46 \mathrm{~cm}$ width.

The genotypes 1, 3, 6, 7, 8 and 10 presented oval fruits and the other

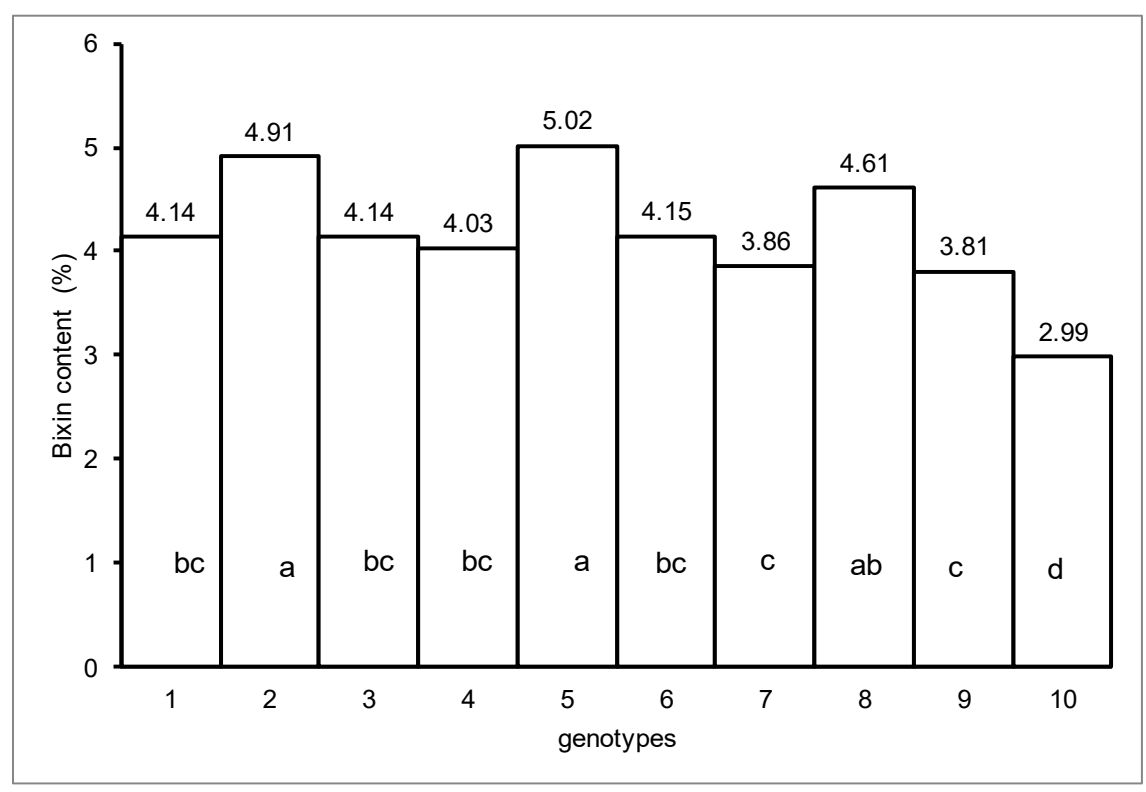

Figure 1. Bixin content in seeds of 10 annatto genotypes. Averages followed by the same letter do not differ by Tukey test at 5\% of probability. Vitória da Conquista, UESB, 2014.

Table 1. $C F=$ fruit length, $\mathrm{LF}=$ fruit width, $\mathrm{NFC}=$ number of fruits per bunch, $\mathrm{NSF}=$ number of seeds per fruit and $\mathrm{MCS}=$ mass of 100 seeds of 10 genotypes of annatto. Vitória da Conquista, UESB, 2014.

\begin{tabular}{lccccc}
\hline Genotype & CF (cm) & LF (cm) & NFC & NSF & MCS (g) \\
\hline 1 & $4.65 \mathrm{~b}$ & $3.43 \mathrm{a}$ & $9.8 \mathrm{~b}$ & $35.6 \mathrm{a}$ & $2.64 \mathrm{e}$ \\
2 & $4.78 \mathrm{~b}$ & $3.12 \mathrm{c}$ & $22.2 \mathrm{a}$ & $42.2 \mathrm{a}$ & $2.60 \mathrm{e}$ \\
3 & $3.81 \mathrm{~d}$ & $3.28 \mathrm{~b}$ & $15.6 \mathrm{~b}$ & $36.4 \mathrm{a}$ & $3.22 \mathrm{~b}$ \\
4 & $4.96 \mathrm{a}$ & $3.32 \mathrm{~b}$ & $15.4 \mathrm{~b}$ & $39.8 \mathrm{a}$ & $2.78 \mathrm{~d}$ \\
5 & $4.93 \mathrm{a}$ & $3.02 \mathrm{c}$ & $17.0 \mathrm{~b}$ & $37.4 \mathrm{a}$ & $2.82 \mathrm{~d}$ \\
6 & $4.31 \mathrm{c}$ & $3.29 \mathrm{~b}$ & $21.2 \mathrm{a}$ & $36.8 \mathrm{a}$ & $3.14 \mathrm{c}$ \\
7 & $4.69 \mathrm{~b}$ & $3.52 \mathrm{a}$ & $12.6 \mathrm{~b}$ & $36.2 \mathrm{a}$ & $3.42 \mathrm{a}$ \\
8 & $4.68 \mathrm{~b}$ & $3.39 \mathrm{~b}$ & $15.6 \mathrm{~b}$ & $43.6 \mathrm{a}$ & $2.88 \mathrm{~d}$ \\
9 & $4.53 \mathrm{~b}$ & $3.09 \mathrm{c}$ & $13.6 \mathrm{~b}$ & $39.4 \mathrm{a}$ & $3.00 \mathrm{c}$ \\
10 & $4.24 \mathrm{c}$ & $3.50 \mathrm{a}$ & $12.0 \mathrm{~b}$ & $34.4 \mathrm{a}$ & $3.00 \mathrm{c}$ \\
\hline $\mathrm{CV}(\%)$ & 3.06 & 3.00 & 28.64 & 20.6 & 4.81 \\
\hline
\end{tabular}

Averages followed by the same letter in the column do not differ by Scott-Knott test at 5\% probability (medias seguidas de mesma letra na coluna não diferem, Scott-Knott, 5\%). 
Table 2. $\mathrm{TB}=$ estimates of genetic parameters for bixin contente, $\mathrm{CF}=$ fruit length, $\mathrm{LF}=$ fruit width, $\mathrm{NFC}=$ number of fruits per bunch and MCS $=$ mass of 100 seeds of 10 genotypes of annatto. Vitória da Conquista, UESB, 2014.

\begin{tabular}{lccccc}
\hline Parameters & TB $(\%)$ & CF $(\mathbf{c m})$ & LF $(\mathbf{c m})$ & NFC & MCS (g) \\
\hline Vp & 0.34 & 111.39 & 26.29 & 15.16 & 0.07 \\
Vg & 0.19 & 95.79 & 18.95 & 11.22 & 0.06 \\
Ve & 0.15 & 15.02 & 7.84 & 3.94 & 0.004 \\
CVP (\%) & 14.69 & 23.15 & 15.70 & 25.12 & 8.39 \\
CVG (\%) & 10.55 & 21.47 & 13.21 & 21.61 & 8.52 \\
CVE (\%) & 18.69 & 8.50 & 8.50 & 12.81 & 2.15 \\
h $(\%)$ & 56.00 & 86.00 & 70.00 & 74.00 & 100.00 \\
G & 0.68 & 18.70 & 7.54 & 5.93 & 0.53 \\
G (\%) & 16.26 & 41.02 & 22.88 & 38.28 & 18.10 \\
\hline Vp &
\end{tabular}

$\mathrm{Vp}=$ phenotypic variance, $\mathrm{Vg}=$ genotypic variance, $\mathrm{Ve}=$ environmental variance, $\mathrm{CVP}(\%)=$ phenotypic coefficient of variation, $\mathrm{CVG}(\%)=$ coefficient of phenotypic variation, $\mathrm{CVE}(\%)=$ coefficient of environmental variation, $h^{2}(\%)=$ broad-sense heritability, $\mathrm{G}=$ genetic gain, $\mathrm{G}$ $(\%)=$ genetic gain based on the average

genotypes presented lanceolate-shaped fruits. Mantovani et al. (2013) classified capsules presenting similar shapes from an artificial cross between the varieties "Fruto verde piloso" and "Fruto vermelho liso".

The number of fruits per bunch (NFC) varied between 9.8 and 22.2. For this trait, the data found showed a wide variability forming a superior group constituted by genotypes 2 and 6 . In the conditions studied, the averages were above to the ones described by Poltronieri et al. (2001) for cultivar Embrapa 37 which was nine fruits per bunch. Different agronomic traits for the same cultivar can be attributed to edaphoclimatic factors, cultural management and their interactions.

The values found for mass of 100 seeds (MCS) were from 2.64 to 3.42 $\mathrm{g}$, being higher than the ones found by Santana (2006) for genotypes of variety Bico de Pato (2.1 to $2.7 \mathrm{~g}$ ). Seeds showing higher mass are the most desirable for the product quality.

In Figure 1, the results for bixin contents which range from 2.99 (genotype 10) to 5.02\% (genotype 5) can be seen. The averages of genotypes 2, 5 and 8 did not differ significantly among them, considering that the genotype 2 and 5 were superior to the others. Moreira et al. (2014) found 4.83\% for contents for the same cultivar studied (Embrapa 37), in the same region (municipality of Eunápolis). Poltroniere et al. (2001) report that "Embrapa 37 " has contents from 5 to $5.5 \%$. The oscillations of levels of bixin for the same cultivar can be attributed to the cultural management, environmental conditions such as humidity, luminosity and temperature and genetic factors.

According to the traits studied, the authors could observe that the commercial crops of cultivar Embrapa 37 have enough genetic variability to allow identification of superior plantarray for producing seeds and bixin contents. These plants can play an important role in crosses, aiming to contribute to breeding programs, as well as to vegetative propagation tests, in order to increase crop productivity in the short run.

The estimates of genetic parameters for traits evaluated in this study are in Table 2. An effective estimate of genetic parameters is a fundamental basis for the success of any breeding program (Farias Neto et al., 2013).

Estimated values of variance related to effect of the genotype $(\mathrm{Vg})$ were higher than the estimated values of the environment (Ve) for all traits evaluated. The authors noticed, as a consequence, high estimate of broad-sense heritability $\left(\mathrm{h}^{2}\right)$ for the same traits. According to Stansfield (1974), heritability values higher than $50 \%$ are considered high.

The high estimate of $h^{2}$ can anticipate that it is easy to select the plants, since phenotype reflects genotype, it means, environment has little influence on the desirable trait (Burton \& DeVane, 1953; Allard, 1960). According to Falconer \& Mckay (1996), the closer to $100 \%$ for heritability, the higher the safety in selecting superior genotypes.

The authors observed low estimates of genetic gain $(\mathrm{G})$ for all traits, except for fruit length (CF). $G$ indicates the type of genetic action involved in the character expression: when it is high, $G$ $(\geq 20)$ indicates additive genetic action and low $\mathrm{G}(0-10)$ indicates non-additive genetic action (Johanson et al., 1955; Singh \& Narayanar, 1993). Heritability should be evaluated together with the genetic gain for a safe breeding program. Low genetic gain and high heritability indicate a non-additive genetic action (Johanson et al., 1955; Eid, 2009).

For CF, the genetic gain was intermediate with a tendency to be high, in this case, since heritability value was high $(86 \%)$ the authors could consider an additive genetic action for this trait, therefore, the selection could be carried out considering the $\mathrm{F}_{1}$ generation.

The results obtained allow the authors to notice a genotypic variation rate for morpho-agronomic traits among plants of cultivar Embrapa 37, with high heritability and non-additive genetic inheritance for bixin content, fruit width (LF), number of fruits per bunch and mass of 100 seeds.

\section{ACKNOWLEDGEMENTS}

To FAPESB by Doctorate scholarship granted to the first author.

\section{REFERENCES}

ALLARD, RW. 1960. Principles of plant breeding. New York: Wiley. 485p.

BALDISSERA, JNC; VALENTINI, G; COAN, MMD; GUIDOLIN, AF; COIMBRA, JLM. 2014. Fatores genéticos relacionados com a herança em populações de plantas autógamas. Revista de Ciências Agroveterinárias13: 181-189.

BRUCKNER, CH; KHOURI, SS; MELGAÇO, AV. 1991. Propagação do urucueiro (Bixa orellana L.) por meio de cinco modalidades de 
enxertia. Revista Ceres 32: 340-344.

BURTON, GW; DEVANE, EH. 1953. Estimating heritability in Tall Fescue (Festuca arundinacea) from replicated clonal material. Agronomy Journal 45: 487-488.

CARVALHO, PRN; SILVA, MG; FABRI, EG; TAVARES, PER; MARTINS, ALM.; SPATTI, LR. 2010. Concentração de bixina e lipídeos em sementes de urucum da coleção do Instituto Agronômico (IAC). Bragantia 69: 519-524.

CRUZ, CD; CARNEIRO, PSC. 2006. Modelos biométricos aplicados ao melhoramento genético. Viçosa: UFV. 586p.

EID, MH. 2009. Estimation of heritability and genetic advance of yield traits in wheat (Triticum aestivum L.) under drought conditions. International Journal of Genetics and Molecular Biology 1: 115- 120.

FABRI, EG; TERAMOTO, JRS. 2015. Urucum: fonte de corantes naturais. Horticultura Brasileira 33: 1 (artigo de capa).

FALCONER, DS; MACKAY, TFC. 1996. Introduction to quantitative genetics. New York: Longman. 464p.

FALESI, IC. 1987. Urucuzeiro: Recomendações básicas para o cultivo. Belém: EmbrapaUEPAE. 27p.

FARIAS NETO, JT; CLEMENT, CR; RESENDE, MDV. 2013. Estimativas de parâmetros genéticos e ganho de seleção para produção de frutos em progênies de polinização aberta de pupunheira no Estado do Pará, Brasil. Bragantia. 72: 122-126.

FERREIRA, DF. 2011. Sisvar: a computer statistical analysis system. Ciência e Agrotecnologia 35: 1039-1042.

FRANCO, CFO; FABRI, EG; BARREIRO NETO, M; MANFIOLLI, MH; HARDER, MNC; RUCKER, NCA. 2008. Urucum: Sistemas de Produção para o Brasil. João Pessoa: Emepa, APTA. 112p.

FRANCO, CFO; SILVA, FCP; CASE FILHO, J; NETO, MB; SÃO JOSÉ, AR; REBOUÇAS, TNH; FONTINELLI, ISC.2002. Urucuzeiro: Agronegócio de Corantes Naturais. João
Pessoa: Emepa. 120p.

JOHANSON, HW; ROBINSON, HF; COMSTOCK, RE. 1955. Estimates of genetic and environmental variability in Soybean. Agronomy Journal 47:314-318.

LYNCH, MC; WALSH, B. 1998. Genetics and analysis of quantitative traits. Sunderland: Sinauer Associates Inc. 980p.

MANTOVANI, NC; GRANDO, MF; XAVIER, A; OTONI, WC. 2010. Resgate vegetativo por alporquia de genótipos adultos de urucum (Bixa orellana L.). Ciência Florestal 20: 405-412.

MANTOVANI, NC; GRANDO, MF; XAVIER, A; OTONI, WC. 2013. Avaliação de genótipos de urucum (Bixa Orellana L.) por meio da caracterização morfológica de frutos, produtividade de sementes e teor de bixina. Ciência Florestal 23: 355-362.

MARMITT, S; PIROTTA, LV; STÜLP, S. 2010. Aplicação de fotólise direta e $\mathrm{UV} / \mathrm{H}_{2} \mathrm{O}_{2}$ a efluente sintético contendo diferentes corantes alimentícios. Química Nova 33: 384-388.

MENDES, AMS; FIGUEIREDO, AF; SILVA, JF. 2005. Crescimento e maturação dos frutos e sementes de urucum. Revista Brasileira de Sementes 27: 25-34.

MOREIRA, VS; REBOUÇAS, TNH; MORAES, MOB; SÃO JOSÉ, AR; SILVA, MV. 2014. Atividade antioxidante de urucum (Bixa orellana L.) in natura e encapsulado. Revista Iberoamericana de Tecnología Postcosecha 15: 201-209.

OYIGA, BC; UGURU, MI. 2010. Genetic variations and contributions of some floral traits to pod yield in bambara groundnut under two cropping seasons in the derived savanna of the South-East Nigeria. International Journal of Plant Breeding 5: 58-63.

POLTRONIERI, MC; MARTINS, CS; RODRIGUES, JE; COSTA, MR; NAZARÉ, RFR. 2001. Novas Cultivares de Urucum: Embrapa 36 e Embrapa 37. Belém: Embrapa Amazônia Oriental, 21p. (Circular Técnica
22).

REBOUÇAS, TNH; SÃO JOSÉ, AR. 1996. A cultura do urucum: práticas de cultivo e comercialização. Vitória da Conquista: UESB. 42p.

SANTANA, KC. 2006. Seleção de genótipos de urucueiros (Bixa orellana L.) da variedade Bico de Pato no Estado da Bahia. Vitória da Conquista: UESB. 63p. (Dissertação mestrado)

SANTANA, KC; GUEDES, PA; REBOUÇAS, TNH; SÃO JOSÉ, AR; LEMOS, OL; VILA, MTR; SOUZA, MJL. 2008. Teores de bixina em urucum (Bixa orellana) 'Piave Vermelha', em diferentes acondicionamentos e temperaturas Tecnologia \& Ciência Agropecuária 2: 19-22.

SÃO JOSÉ, AR; REBOUÇAS, TNH; SOUSA, PJS; SOUZA, IVB. 1992. Seleção de urucueiros (Bixa orellana) superiores do tipo cultivado bico de pato na região de Vitória da Conquista-BA. Revista Brasileira de Corantes Naturais 1: 106-113.

SILVA, FCP; FRANCO, CF. 2000. Urucueiro uma alternativa de agronegócio. João Pessoa: EMEPA. 64p.

SINGH, P; NARAYANAN, SS. 1993. Biometrical techniques in plant breeding. New Delhi: Kalayani publishers. 83p.

STANSFIELD, WD. 1974. Genética. São Paulo: McGraw-Hill do Brasil. 958p.

SUNDAY, OF; AYODELE, AM; BABATUNDE, KO; OLUWOLE, AM. 2007. Genotypic and phenotypic variability for seed vigour traits and seed yield in West African Rice (Oryza sativa L.) genotypes. Journal of American Science 3: 34-41.

YABIKU, HY; TAKAHASHI, MY. 1991. Avaliação dos métodos analíticos para determinação da bixina em grãos de urucum e suas correlações. In: SIMPÓSIO INTERNACIONAL DE URUCUM, Anais... Campinas: ITAL. 275-279. 